Discussion Paper No. 13-001

\title{
Nonlinearity in Cap-and-Trade Systems: \\ The EUA Price and its Fundamentals
}

Benjamin Johannes Lutz, Uta Pigorsch, and Waldemar Rotfuß

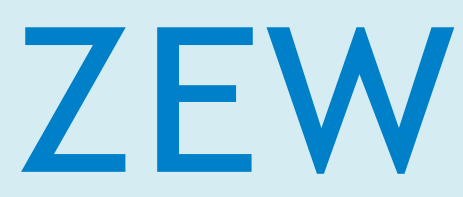

Zentrum für Europäische Wirtschaftsforschung $\mathrm{GmbH}$

Centre for European

Economic Research 
Discussion Paper No. 13-001

\title{
Nonlinearity in Cap-and-Trade Systems: The EUA Price and its Fundamentals
}

\author{
Benjamin Johannes Lutz, Uta Pigorsch, \\ and Waldemar Rotfuß
}

Download this ZEW Discussion Paper from our ftp server:

http://ftp.zew.de/pub/zew-docs/dp/dp13001.pdf

Die Discussion Papers dienen einer möglichst schnellen Verbreitung von neueren Forschungsarbeiten des ZEW. Die Beiträge liegen in alleiniger Verantwortung der Autoren und stellen nicht notwendigerweise die Meinung des ZEW dar.

Discussion Papers are intended to make results of ZEW research promptly available to other economists in order to encourage discussion and suggestions for revisions. The authors are solely responsible for the contents which do not necessarily represent the opinion of the ZEW. 


\section{Das Wichtigste in Kürze}

Seit der Einführung des EU-Emissionshandelssystems (EU-EHS) im Jahr 2005 ist ein neues Forschungsgebiet innerhalb der angewandten Ökonometrie entstanden, das die Preisbildung von EU-Emissionszertifikaten (EUA) analysiert: Carbon Finance. $\mathrm{CO}_{2}$-Preise beeinflussen als Kostenfaktor das operative Geschäft sowie die langfristige Planung der durch das EU-EHS regulierten Unternehmen. Daher sind Erkenntnisse über die Dynamik der EUA-Preise für Praktiker, Politiker und Wissenschaftler von hoher Bedeutung. Dieses Papier leistet einen Beitrag zur Untersuchung des Zusammenhangs zwischen der Entwicklung des EUA-Preises und dessen fundamentalen Determinanten, wie z.B. den Energiepreisen, der makroökonomischen Entwicklung und den Wetterbedingungen in Europa. Mit Hilfe eines Markov Regime-Switching GARCH Modells wird der nichtlineare Einfluss dieser Determinanten auf den EUA-Preis geschätzt. Das Modell erlaubt außerdem Einblicke in die Entwicklung des Ausmaßes der Schwankungen (Volatilität) des EUA-Preises über die Zeit.

Brüche und Veränderungen des Daten generierenden Prozesses, welcher der EUA-PreisZeitreihe zu Grunde liegt, sind eine Konsequenz der Ausgestaltung des EU-EHS. In einem Emissionshandelssystem wie dem EU-EHS ist das aggregierte Angebot an Emissionszertifikaten fix, während die Nachfrage zahlreichen Veränderungen und Schocks unterliegt. Wenn ein Einbruch der wirtschaftlichen Aktivitäten zu einem starken Einbruch der Emissionen und somit zu einer sinkenden Nachfrage nach Zertifikaten führt, so hat dies zur Folge, dass die Unsicherheit unter den Marktteilnehmern über die Knappheit an Zertifikaten in der gegenwärtigen Handelsphase zunimmt. Die damit verbundenen Handelsaktivitäten führen zu einer erhöhten Volatilität des EUA-Preises und zu einem veränderten Zusammenhang zwischen den fundamentalen Determinanten und dem Zertifikatepreis. Das empirische Modell identifiziert zwei unterschiedliche Marktzustände (Regime), die den Verlauf des EUA-Preises bestimmen. Im Betrachtungszeitraum der durchgeführten Untersuchung von Januar 2007 bis August 2010 wechselt der Daten generierende Prozess mehrfach zwischen diesen beiden Zuständen. Das erste Regime ist durch keinen klaren Preistrend charakterisiert, weist jedoch hohe Schwankungen im EUA Preisverlauf aus. Dieser Zustand kann als eine Phase der Desorientierung am Markt interpretiert werden. Im Gegensatz dazu beschreibt das zweite Regime einen Zustand, in dem sich der EUA-Preis in einem Aufwärtstrend befindet und geringeren Schwankungen unterliegt. Das Modell ordnet das erste Regime vor allem Perioden während der Rezession in den Jahren 2008 und $2009 \mathrm{zu}$, einer Phase sinkender Gesamtemissionen. Die Ergebnisse zeigen zudem, dass die Energiepreise in beiden Regimen wichtige EUA-Preis-Determinanten sind. Die Preise von Öl und Gas haben einen stärkeren Einfluss auf den EUA-Preis während der Phasen, in denen das zweite Regime vorherrscht. Aktien- und Rohstoffindices, die als kurzfristige Indikatoren für die gesamtwirtschaftliche Lage dienen, haben hingegen einen stärkeren Einfluss, wenn das erste Regime vorherrscht. Die Marktteilnehmer richten ihr Handeln demnach stärker nach Indikatoren der wirtschaftlichen Lage in Phasen höherer Unsicherheit. Extreme Temperaturen haben keinen signifikanten Einfluss auf den EUA-Preis.

Die Ergebnisse der empirischen Untersuchung unterstützen die Hypothese, dass die Dynamik des EUA-Preises durch Brüche und Veränderungen gekennzeichnet ist. Dies bezieht sich auf den Zusammenhang zwischen fundamentalen Determinanten und dem EUA-Preis selbst, aber auch auf die Entwicklung der Schwankungsbreite über den Betrachtungszeitraum hinweg. 


\section{Nontechnical Summary}

Since the introduction of the EU Emissions Trading System (EU ETS) in 2005, a new area of research has developed within the field of applied econometrics: Carbon Finance. Carbon Finance focuses on the analysis of the price formation of emission credits and allowances. As driving cost factor, prices of European Union Allowances (EUAs) influence operational business and long-term planning of EU ETS regulated firms. Therefore, the understanding of the EUA price dynamics are significant for practitioners, politicians and scientists. This paper contributes to the analysis of the relationship between the EUA price and its fundamentals, such as energy prices, indicators of the macroeconomic development and weather conditions in Europe. Based on a Markov regime-switching model, we estimate the nonlinear impact of these fundamentals on the EUA price. Further, the model allows to get insights into the development of the EUA price variation (volatility) over time.

Breaks and changes in the data generating process that underlies the EUA price time series are a consequence of the design of the EU ETS. Emissions trading schemes are characterized by a fixed supply of allowances, while the demand is subject to various shocks and changes. A sudden decline of economic activities, for example, leads to decreasing emissions and hence to a decreasing demand of allowances. As a consequence, this situation increases uncertainty among market participants about the overall stringency of the scheme. The associated trading leads to higher levels of EUA price volatility and to a changing relation between the EUA price and its fundamentals. The empirical model identifies two different market states (regimes), that determine the EUA price dynamics. The data generating process switches several times between these two regimes during the period under consideration, i.e. January 2007 to August 2010. The first regime is characterized by no clear price trend, but high levels of EUA price variation. This state can also be interpreted as a market phase of disorientation. In contrast, the second regime describes a state where the EUA price exhibits a positive trend and where the variation in prices is on a lower level. The appearance of the first regime coincides with the economic recession in 2008 and 2009, a period characterized by decreasing aggregate emissions. The results show in addition, that energy prices are important EUA price determinants in both regimes. The prices for oil and gas have a stronger influence in phases where the second regime prevails. On the contrary, equity and commodity indices that serve as short term indicators for the macroeconomic development have a stronger influence when the first regime occurs. Extreme temperatures have no significant influence on the EUA price.

The results of the empirical examination support the hypotheses, that the EUA price dynamics are characterized by breaks and changes. The impact of fundamentals on the EUA price and the development of its variation over time are subject to this kind of nonlinearity. 


\title{
Nonlinearity in Cap-and-Trade Systems: The EUA Price and its Fundamentals
}

\author{
Benjamin Johannes Lutz, Uta Pigorsch† Waldemar Rotfuß $\aleph^{\ddagger}$ \\ *Centre for European Economic Research, Mannheim, Germany \\ †University of Mannheim, Mannheim, Germany \\ ‡Freudenberg \& Co., Weinheim, Germany
}

January 2, 2013

\begin{abstract}
In this paper we examine the nonlinear relation between the EUA price and its fundamentals, such as energy prices, macroeconomic risk factors and weather conditions. By estimating a Markov regime-switching model, we find that the relation between the EUA price and its fundamentals varies over time. In particular, we are able to identify a low and a high volatility regime, both showing a strong impact of the fundamentals on the EUA price. The high volatility regime is predominant during the recession of 2008 and 2009 - a time period in which the actual emissions sharply decreased due to the economic crisis.
\end{abstract}

Keywords: EU ETS, EUA Price Fundamentals, Markov Regime-Switching JEL Classification: C22, C58, G13, Q50

${ }^{*}$ Corresponding author: Benjamin Johannes Lutz, Centre for European Economic Research (ZEW), Mannheim, P.O. Box 1034 43, 68034 Mannheim, Germany, E-mail: lutz@zew.de; Phone: +49/621/1235/204, Fax: +49/621/1235/226.

†Department of Economics, University of Mannheim, L7 3-5, 68131 Mannheim, Germany, E-mail: uta.pigorsch@vwl.uni-mannheim.de; Phone: +49/621/181/1945.

${ }^{\ddagger}$ Freudenberg \& Co. Kommanditgesellschaft, 69465 Weinheim, Germany, E-mail: waldemar.rotfuss@freudenberg.de; Phone: + 49/6201/80/3552. 


\section{Introduction}

This paper investigates the changing nature of the relation between the European Union Allowance (EUA) price and its fundamentals. The EUA price dynamics and its driving factors have been of great importance for practitioners, politicians and scientists since the introduction of the European Union Emissions Trading Scheme (EU ETS) in 2005. The reasons for the interest are manifold. First, carbon prices introduce an additional cost component affecting day-to-day and long-term operations of regulated installations. Understanding this cost component is a key strategic element for many regulated installations to achieve long-term cost efficiency. Second, the scheme is a market-based policy instrument. Its success heavily depends on its ability to generate correct price signals that fully account for the underlying fundamentals. Thus, the relation between the EUA price and its driving factors is crucial for the understanding of the effectiveness of the scheme.

We argue that the varying relation between the EUA price and its fundamentals is a consequence of the design of the EU ETS. In cap-and-trade systems, as in the case of the EU ETS, the regulatory authority determines the total number of allowances for a certain period of time. In other words, the aggregated supply of allowances is fixed and therefore inelastic. In contrast, the demand varies due to various shocks, for example positive and negative shocks to the macroeconomic activity. Such shocks shift the production of goods to higher or lower levels, which increases or decreases the aggregated level of emissions and, thus, the demand for allowances. As a result, market participants adjust their expectations about the overall stringency of the scheme. We hypothesize, that this situation translates into a higher volatility and a varying relation between the EUA price and its fundamentals.

The recent literature provides empirical evidence on structural changes in the data generating process of the EUA prices. Alberola, Chevallier, and Chèze (2008), Chevallier (2009), Keppler and Mansanet-Bataller (2010) and Hintermann (2010) devote their research to the detection of price determinants affecting the European carbon market. In particular, they quantify the linear impact of fundamentals such as commodity prices, weather conditions and economic fluctuations on the EUA price. To account for potentially time-changing influences of the fundamentals they conduct an analysis over different subsamples. In doing so, they assume that the timing of the structural breaks are known. The authors trace these structural changes back to different factors: Alberola, Chevallier, and Chèze (2008) refer to the information disclosure on the actual emissions in 2006 as a reason for structural changes, whereas Chevallier (2009) sees the aftermath of the financial crisis as a factor causing breaks. These potential sources for breaks seem to have 
one characteristic in common: They alter the expectations about the overall demand of allowances during the prevailing compliance period and, thus, affect the expectations about the overall stringency of the EU ETS. Therefore, these changes are inherent in the cap-and-trade system and should be endogenized.

In contrast to the earlier studies, we do not assume the changes in regimes to be deterministic. Instead, we employ a Markov regime-switching model to examine the impact of the fundamentals on the EUA returns. The switches between different regimes are modeled by a hidden Markov chain. In our empirical analysis we identify two volatility regimes, in which the impacts of the fundamentals differ only slightly. Moreover, the state probabilities coincide approximately with the recent economic recession of 2008 and 2009 - a period characterized by one of the worst modern recessions which clearly lowered the demand for EUAs. Our model indicates high levels of volatility for this period reflecting the uncertainty in the EUA market.

The remainder of the paper is organized as follows. Section 2 gives a brief overview of the regulatory design of the EU ETS. Section 3 discusses former research on the relation between EUA prices and its fundamentals. Section 4 describes the data and Section 5 provides the econometric models used in the analysis. Section 6 presents the empirical results, while Section 7 concludes.

\section{European carbon trading in a nutshell}

The EU ETS is one of the key instruments in European climate policy encompassing approximately 50 percent of the total European carbon dioxide emissions. Based on the Directive 2003/87/EC, it was launched in 2005 as the first multinational carbon trading scheme. Designed as cap-and-trade system, it directs pollutant emissions via tradable permits in order to achieve emission reduction targets in a cost-effective and economically efficient way. The regulating institutions set an emission cap for a certain time period - the compliance period - and accordingly allocate a fixed amount of tradable permits among the market participants. Thus, the overall supply of permits is fixed for the considered compliance period. The EU ETS is temporally separated by three compliance periods (Phase I: 2005-2007; Phase II: 2008-2012; Phase III: 2013-2020). Currently, the scheme regulates installations from the power sector and emission-intensive industry sectors such as oil refinement, production and processing of ferrous metals, lime, cement, glass, ceramics, pulp and paper. In addition to carbon dioxide $\left(\mathrm{CO}_{2}\right)$ emissions, the EU ETS covers the greenhouse gases methane $\left(\mathrm{CH}_{4}\right)$, nitrous oxide $\left(\mathrm{N}_{2} \mathrm{O}\right)$, hydrofluorocarbons (HFCs), perfluorocarbons (PFCs) and sulphur hexafluoride $\left(\mathrm{SF}_{6}\right)$. The issuance of allowances takes 


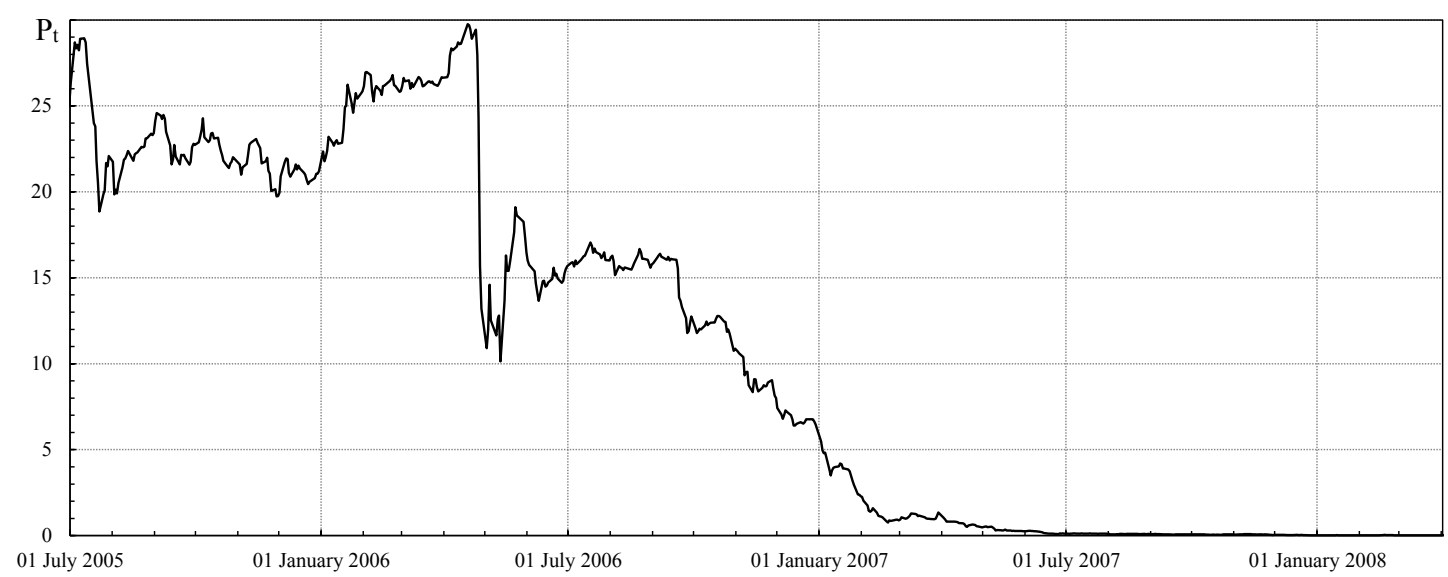

Figure 1: EUA price development during Phase I.

place gradually, while monitoring, reporting and verification of the actual emissions and the delivery of the equivalent amount of EUAs or credits from project-based mechanisms are executed annually.

Phase I is widely seen as the pilot period for newly established institutions and market participants. For Phase I and Phase II the overall emission cap is defined by the National Allocation Plans (NAPs). The NAPs are determined by each member state and define the national total of permits and the mode of allocation. By approving the NAPs, the European Commission (EC) settles the overall cap. When in early 2006 the information about the actual emissions was released, the market participants began to realize that the overall emission cap for Phase I was not restrictive. Moreover, as neither borrowing nor banking of allowances was allowed between Phase I and Phase II the price for EUAs issued for Phase I collapsed, as is displayed in Figure 1. The regulating institutions took this experience as a reason to connect Phase II and Phase III via banking. Banking of spare allowances extends the time span that is considered by market participants when forming expectations about the overall stringency of the scheme. Thus, banking reduces the exposure and risk of dramatic price drops to a level near zero. Nevertheless, shocks still lead to price adjustments and affect the volatility.

During Phase I and Phase II the main allocation mechanism was "grandfathering" the allocation for free, based on historical emissions. In Phase III the EC will directly fix the EU-wide cap without the indirect way of approving NAPs. The allocation mode will gradually switch to auctioning as the main allocation mechanism. The cap-setting will be stricter (the total amount of 2,04 bn tonnes of carbon dioxide equivalent in 2013 will be lowered by 1.74 percent annually until 2020) and more sectors (e.g. production and processing of non-ferrous metals) will be regulated from 2013 onwards. For a more 
detailed description of the changes in Phase III, refer to Directive 2009/29/EC.

Since the introduction of the scheme in 2005, highly efficient EUA spot and derivative markets have evolved. In 2011, the total transaction value in the EU ETS was EUR 122.3 bn including credits from the project-based mechanisms (World Bank 2012). The market has been growing rapidly during the first two commitment periods and is now the largest emission market in the world. Several types of transactions and trading products have evolved: EUAs can be traded via bilateral, over-the-counter or organized markets. In addition to the spot market, there is a lively exchange of futures, options and swaps between the interest groups. Whereas bilateral and over-the-counter transactions dominated during the first compliance period, volumes traded on exchanges increased heavily since the beginning of the Phase II. The most liquid derivatives market is situated at the European Climate Exchange (ICE/ECX; London) where approximately 90 percent of the futures contracts are traded. The most liquid spot market is Bluenext (Paris). About 70 percent of the daily spot transactions are settled at this exchange.

\section{Related Literature}

There already exist several studies that focus on the relation between EUA prices and its determinants. Most of this research is primarily concerned with the existence of various fundamentals and their effects on the EUA price, such as the effects of energy prices, risk factors or weather conditions. Mansanet-Bataller, Pardo, and Valor (2007), Alberola, Chevallier, and Chèze (2008), and Hintermann (2010) provide evidence for a strong impact of energy prices and extreme temperatures, while Alberola, Chevallier, and Chèze (2009a) and Alberola, Chevallier, and Chèze (2009b) show that also the industrial production of emission intensive sectors affect the EUA price development. Directing the view towards the influence of macroeconomic fluctuations, Chevallier (2009) considers macroeconomic risk factors, which reflect short- and medium-term sentiments in the financial markets about the macroeconomic development. Although macroeconomic risk factors are important determinants for energy commodity futures, their impact on EUA futures appears to be weak. Conrad, Rittler, and Rotfuß (2011) provide evidence that information shocks on regulatory issues and the macroeconomic activity clearly impact EUA prices. According to Anger and Oberndorfer (2008), Oberndorfer and Rennings (2007), Klepper and Peterson (2004), and Demailly and Quirion (2008), the reverse effects of the EU ETS on macroeconomic activity are very weak. The studies of Keppler and Mansanet-Bataller (2010) and Bredin and Muckley (2011) place emphasis on the causal relationships between EUA prices and its fundamentals or their long-term equilibrium relationship. 
Overall, the effects of the fundamentals such as energy prices, the weather, the current and future macroeconomic activity and selected macroeconomic risk factors on carbon prices are clearly evident. The extent and direction of the impact of these fundamentals is, however, not constant over time and highly depends on the sample considered. Moreover, structural changes are an important feature of the EUA price generating process. While Alberola, Chevallier, and Chèze (2008) see regulatory announcements as the main reason for those breaks, Chevallier (2009) argues that structural breaks are primarily due to changes in expectations. Recently, Chevallier (2011a), Chevallier (2011b) and Peri and Baldi (2011) adopt nonlinear models to analyze the long-term equilibrium relationship between the EUA price and its determinants. Their empirical evidence suggests that the European industrial production index and oil prices are likely to influence (eventually asymmetrically and depending on the regime) the EUA price, while reverse effects are not present. In contrast to these studies that focus on long-term relationships, we devote our attention to the short-term consequences of structural changes in the data-generating process. By endogenizing structural breaks and allowing simultaneously for heteroscedasticity, we are able to estimate the short-run relationship between the EUA price and its fundamentals more precisely. Further, we exploit more recent daily data of EUA futures return series spanning from January 2007 to August 2010.

\section{Data}

Based on the previous studies we take into account several different fundamentals of EUA prices. In the following we present these fundamentals, the construction of the EUA price series, and provide an analysis of the empirical properties of the considered series.

\subsection{EUA prices and their fundamentals}

Our empirical analysis exploits data on carbon and energy commodity prices, indicators for macroeconomic risk as well as deviations from the mean temperature in Europe. Our sample period ranges from January 3, 2007 until August 16, 2010, resulting in 941 daily observations. To obtain a representative carbon price we follow Chevallier (2009) and use data from the ICE Futures/European Climate Exchange (ECX) which is the most liquid market for carbon derivatives in Europe. We consider annual futures, which expire in December, for 2008 up to 2010, and construct the EUA price series based on the daily closing EUA futures prices (EUR/tCO2e) of the contract with the closest maturity. This assures the use of the most liquid and, therefore, most relevant futures contract in the construction of the price series. The same procedure is applied to energy commodity 
futures mentioned below. The resulting daily closing prices are used to construct the series of continuously compounded returns, i.e. the first difference of the logarithmic prices.1

The link between EUA prices and prices for steam coal, gas and oil exists mainly because some industries covered by the EU ETS have the ability to switch among various fuels in their production process, see e.g. Mansanet-Bataller, Pardo, and Valor (2007), Alberola, Chevallier, and Chèze (2008) and Hintermann (2010). Based on different emission and energy intensities, alterations in the price ratio of coal, gas and oil affect the demand for EUAs and therefore their price. The fuel switch behavior might cause a reciprocal relationship between carbon and energy commodity prices. However, we assume that the influence of the regionally limited EU ETS on the price formation of the global market for fossil fuels is negligible. In the recent study by Peri and Baldi (2011), this argument finds empirical support. The most important reference price for steam coal in Europe is the API2 index published by Argus/McCloskey's Coal Price Service. For our investigations, we employ corresponding API2 index futures prices (USD/t) of annual contracts traded at the European Energy Exchange (EEX). The liquidity of these futures is low due to the fact that a large part of the coal is directly traded via brokers whose transactions are in turn the basis of the API2. Nevertheless, the futures prices are representative, because they are calculated based on fair values enquired from trading members and brokers. In the following, "Gas" refers to the gas price series (EUR/MWh) based on annual futures contracts traded at the European Energy Derivatives Exchange (ENDEX), which is the largest gas exchange in Europe. Further, we employ the closing prices of the Crude OilBrent Current Month Free On Board. Like for the steam coal futures, the price of the crude oil futures is quoted in USD. We use the EUR/USD Reference Rate published by the European Central Bank (ECB) to convert the coal and oil price series into EUR. We refer to the resulting series as "Coal" and as "Oil".

Fama and French (1989) and Sadorsky (2002) have shown the importance of macroeconomic risk factors for the formation of expectations on the equity, bond and commodity markets. Following Chevallier (2009) we also assume macroeconomic risk factors to influence carbon markets. We expect the EUA price to fall, when the macroeconomic risk measures indicate a prospective economic slow down. This relationship is based on the assumption that adverse business conditions lower aggregated demand and therefore reduce the demand for EUAs. We therefore consider a stock index, a commodity index, a yield spread and a term spread as measures for macroeconomic and financial risks. The stock index measures the development of the financial markets and serves as predictor

\footnotetext{
${ }^{1}$ Throughout the paper we make exclusive use of daily closing prices and always consider continuously compounded returns expressed in percentage points, unless stated otherwise.
} 
for fluctuations of the overall economic environment. Stock prices reflect expectations about future dividends and can be interpreted as leading indicators for the development of business conditions. We include into our analysis the Dow Jones EURO STOXX 50 (DJES50) which represents a broad portfolio of 50 European companies that are leading in their industries. The index covers different branches such as energy generation, heavy industries and financial institutions. We further consider an indicator capturing risk related to fluctuations at the global commodity markets, i.e. the Thomson Reuters/Jeffries Commodity Research Bureau Index (CRBI), which reflects the development of a broad basket of commodities. It comprises energy, agricultural, metal and soft commodities. The prices of commodities are expected to decrease in times of lowering economic activity induced by decreasing aggregated demand.

To account for default risks in credit markets, we include the default spread defined as the difference between two yields to maturity of two fixed income portfolios which represents the premium required to compensate a lender for investing in the riskier asset. In our case, we use data of average annual yields of U.S. corporate long-term bonds rated AAA and BAA, that are published by Moody's. Empirical findings by Fama and French (1989) provide evidence that the default spread rises in times of high economic uncertainty. The findings are congruent with the development of the default spread in our data set. Thus, we expect the EUA price to decrease, when the default spread declines.

Following Fama and French (1989), we also consider a second interest rate spread reflecting a temporal risk premium. This term spread measures the difference between the yields of maturity of two bonds with different times to maturity. Apart from that, the considered securities have to be endowed with identical properties. It can be interpreted as a compensation for capital contributors for their investment in long-term assets. We compute the term spread as the difference between the ten year spot interest rate and the three-month spot interest rate provided by the ECB euro yield curve. We expect the term spread to rise in times of economic contraction setting pressure on carbon prices.

Similar to Mansanet-Bataller, Pardo, and Valor (2007) and Hintermann (2010), we also include variables reflecting extreme weather conditions into our analysis. In particular, we consider absolute deviations from average temperatures. The deviation is computed as difference between the daily measured temperature and the mean of the monthly temperature averages over the years from 2005 up to 2010. The basis for the series, to which we simply refer as "Temperature", is the Tendances Carbone European Temperature Index, which is obtained as the weighted average of the daily European temperatures.2 The

\footnotetext{
${ }^{2}$ The Tendances Carbone European Temperature Index is computed as NAP weighted average of the daily temperature of the Metnext Weather Indices of 4 countries (German, Italy, France and UK) from January 2005 to end October 2009 and of temperature data of 18 countries since September 2009. The
} 
Table 1: Descriptive statistics.

\begin{tabular}{lrrrrrrrr}
\hline \hline Series & Mean & Median & St. Dev. & Skewness & Kurtosis & Min & Max & Jarque-Bera $^{1}$ \\
\hline EUA & -0.0217 & 0.0557 & 2.5172 & -0.1591 & 4.8396 & -9.4346 & 11.3659 & 136.7 \\
Oil & 0.0271 & 0.0747 & 2.3829 & -0.0517 & 7.7465 & -13.0236 & 15.5739 & 883.8 \\
Coal & 0.0208 & 0.0638 & 1.7884 & -0.6825 & 7.5544 & -10.1216 & 8.5734 & 886.4 \\
Gas & -0.0432 & -0.0130 & 1.7646 & 0.3902 & 5.6415 & -7.4032 & 9.2119 & 297.5 \\
DJES50 & -0.0450 & 0.0000 & 1.7984 & 0.1417 & 8.6109 & -8.2076 & 10.4377 & 1238 \\
CRBI & 0.0227 & 0.0384 & 0.6459 & -0.8881 & 7.5624 & -3.8203 & 2.3149 & 939.9 \\
Default Spread & 0.0335 & 0.0000 & 2.0510 & 0.7231 & 24.8811 & -19.5060 & 18.2322 & $1.9 \mathrm{e}+4$ \\
Term Spread & 0.1677 & 0.0000 & 18.8880 & 1.9559 & 52.6177 & -193.4481 & 225.2515 & $9.7 \mathrm{e}+4$ \\
Temperature & -0.0584 & -0.0007 & 2.6165 & -0.1095 & 2.9284 & -7.5449 & 7.7907 & 2.082 \\
\hline \hline
\end{tabular}

${ }^{1}$ Reported are the Jarque-Bera test statistics. The corresponding critical value is 5.99.

weights are the shares of the NAPs in the considered countries. Extremely high or low temperatures increase the demand for heating or cooling and raise therefore emissions as well as EUA prices. For our empirical analysis we consider absolute values of the deviations from average temperatures.

\subsection{Empirical analysis}

Table 1 highlights the empirical properties of the employed data. Obviously, the mean and median values of all return series are very small. The same is true for the temperature deviation. The mean is in all cases not significantly different from zero. The estimated skewness indicates that especially the distribution of the returns of the term spread is asymmetric. All time series, with the exception of the temperature deviations, clearly exhibit excess kurtosis. The Jarque-Bera test rejects the null hypothesis of zero skewness and kurtosis of three for all eight return series. According to the test statistics of the Augmented Dickey-Fuller (ADF) test and the Phillips-Perron test (PP), which are reported in Table 2, the logarithms of energy prices and macroeconomic and financial risk factors are nonstationary, while the corresponding continuously compounded returns seem to be stationary. The sample autocorrelation function of the squared EUA returns, depicted in Figure 2 along with the corresponding 95\% Bartlett confidence intervals, is slowly decaying, which is typical for daily returns showing volatility clustering and has also already been observed for emission allowance returns by Paolella and Taschini (2008).

Having investigated the main properties of our data, we conclude that it reflects all stylized facts of daily financial return series. The results of the unit root tests also suggest that the series of absolute deviations from average temperatures is stationary.

Metnext Weather Indices are intra-country temperature averages weighted by population. We are grateful to CDC Climat for kindly providing us this data. 


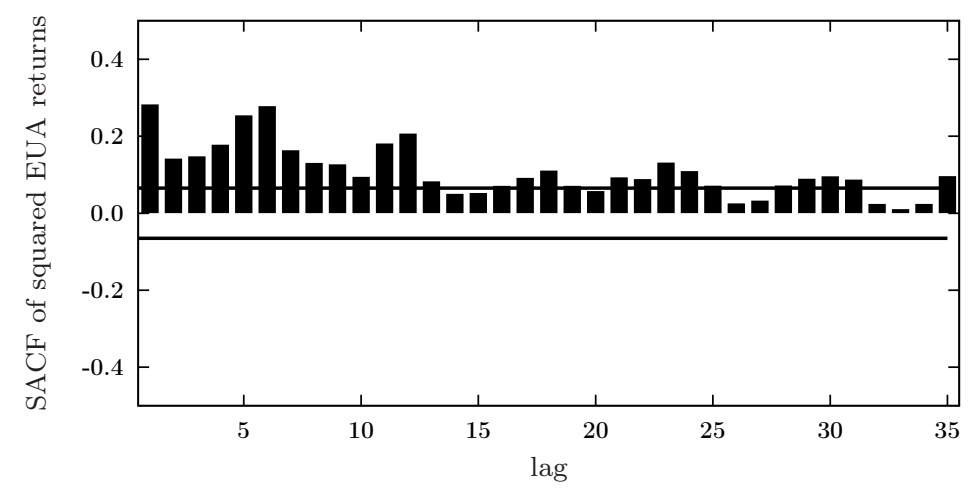

Figure 2: Sample autocorrelation function of the squared EUA returns.

In the remainder of the paper, we consider the stationary time series, i.e. continuously compounded returns of futures prices and risk factors as well as absolute deviations from average temperatures.

\section{$5 \quad$ Methodology}

We model the changing nature of the relation between the EUA price and its fundamentals via a Markov regime-switching (MRS) model (Hamilton 1989). The model is very flexible and, thus, able to describe quite complex dynamics of the considered time series. The model used in this paper is based on Gray (1996) and Klaassen (2002), who extend Hamilton's original approach by including a generalized autoregressive conditional heteroscedasticity (GARCH) structure into the MRS model. The model allows for structural changes in financial volatility, which may generate the observed persistence in volatility, see e.g. Diebold and Inoue (2001), Granger and Hyung (2004) and Mikosch and Stărică (2004). Furthermore, Paolella and Taschini (2008) and Chevallier (2009) prove, that EUA return series based on daily data show characteristics such as volatility clustering and fat tails. They therefore advocate using GARCH-type models in order to take these stylized facts of asset returns into account when considering EUA return series.

The model is based on the assumption that the data generating process shifts at different points of time and that these discrete aperiodic shifts between a finite number of states or regimes are driven by a hidden Markov chain. In the following we briefly explain the model structure in more detail. To this end let $r_{t}$ denote the daily continuously compounded EUA return at time period $t(t=1,2, \ldots, T)$ and let $s_{t} \in\{0,1\}$ be a latent state-variable that governs the change between two possible regimes. The EUA returns are assumed to be affected by $k$ fundamentals, which are subsumed in the vector 
Table 2: Unit root tests.

\begin{tabular}{|c|c|c|c|c|c|c|c|c|}
\hline \multirow[b]{3}{*}{ Series } & \multicolumn{4}{|c|}{ Augmented Dickey-Fuller test } & \multicolumn{4}{|c|}{ Phillips-Perron test } \\
\hline & \multicolumn{2}{|l|}{$p_{t}$} & \multicolumn{2}{|l|}{$r_{t}$} & \multicolumn{2}{|l|}{$p_{t}$} & \multicolumn{2}{|l|}{$r_{t}$} \\
\hline & test statistic & p-value & test statistic & $\mathrm{p}$-value & test statistic & $\mathrm{p}$-value & test statistic & $\mathrm{p}$-value \\
\hline EUA & -1.298 & 0.6299 & -23.181 & 0.0000 & -1.369 & 0.5971 & -27.714 & 0.0000 \\
\hline Oil & -1.508 & 0.5294 & -30.780 & 0.0000 & -1.495 & 0.5357 & -30.780 & 0.0000 \\
\hline Coal & -1.470 & 0.5482 & -27.758 & 0.0000 & -1.598 & 0.4846 & -27.856 & 0.0000 \\
\hline Gas & -1.196 & 0.6753 & -26.167 & 0.0000 & -1.206 & 0.6709 & -26.200 & 0.0000 \\
\hline DJES50 & -1.206 & 0.6708 & -32.209 & 0.0000 & -1.124 & 0.7055 & -32.209 & 0.0000 \\
\hline CRBI & -1.270 & 0.6428 & -10.151 & 0.0000 & -0.917 & 0.7823 & -10.151 & 0.0000 \\
\hline Default Spread & -1.438 & 0.5638 & -31.805 & 0.0000 & -0.996 & 0.7548 & -31.972 & 0.0000 \\
\hline Term Spread & -0.905 & 0.7863 & -12.885 & 0.0000 & -0.878 & 0.7952 & -37.991 & 0.0000 \\
\hline Temperature & -11.046 & 0.0000 & - & - & -10.066 & 0.0000 & - & - \\
\hline
\end{tabular}

Reported are the Augmented Dickey-Fuller test statistics and the Phillips-Perron test statistics along with the corresponding p-values on the null of no unit root in the logarithmic price series $p_{t}$ as well as in the continuously compounded return series $r_{t}$.

$\boldsymbol{x}_{t}^{\prime}=\left(1, x_{1 t}, x_{2 t}, \ldots, x_{k t}\right)$. The influence of these fundamentals on the EUA returns is allowed to vary over time, which is highlighted by the superscript $s_{t}$ on the parameter vector $\gamma^{\left(s_{t}\right)}$. In particular, we assume that the impact depends on the current state $s_{t}$. The mean equation of our model is therefore given by

$$
r_{t}=\boldsymbol{x}_{t}^{\prime} \gamma^{\left(s_{t}\right)}+a_{t}
$$

where the parameter vector $\gamma^{\left(s_{t}\right)^{\prime}}=\left(\gamma_{0}^{\left(s_{t}\right)}, \gamma_{1}^{\left(s_{t}\right)}, \gamma_{2}^{\left(s_{t}\right)}, \ldots, \gamma_{k}^{\left(s_{t}\right)}\right)^{\prime}$ with $s_{t} \in\{0,1\}$ measures the influence of the risk factors on EUA returns in the two regimes.

To account for the possibility of structural changes in the volatility process, we follow Klaassen (2002) and assume that the innovation $a_{t}$ is normally distributed with zero mean and variance $\operatorname{Var}\left(a_{t} \mid s_{t}, I_{t-1}\right)$ conditional on the regime path $\tilde{s}_{t}=\left(s_{t}, s_{t-1} \ldots\right)$ and the information set $I_{t-1}$ containing the information available at time $t-1$ :

$$
a_{t} \mid I_{t-1}, \tilde{s}_{t} \sim N\left(0, \operatorname{Var}\left(a_{t} \mid s_{t}, I_{t-1}\right)\right) .
$$

The dynamics of the conditional variance $\operatorname{Var}\left(a_{t} \mid s_{t}, I_{t-1}\right)$ is based on a GARCH $(1,1)$ model, where, however, the parameters of the conditional variance equation are also allowed to be state dependent, i.e. the conditional variance is given by

$$
\operatorname{Var}\left(a_{t} \mid I_{t-1}, \tilde{s}_{t}\right)=\omega^{\left(s_{t}\right)}+\alpha^{\left(s_{t}\right)} a_{t-1}^{2}+\beta^{\left(s_{t}\right)} E\left[\operatorname{Var}\left(a_{t-1} \mid \tilde{s}_{t-1}, I_{t-2}\right) \mid s_{t}, I_{t-1}\right] .
$$

The development of $s_{t}$ and therefore the switching in regimes is governed by a homogenous first order Markov chain and can be fully described by the transition probabilities $p$ and $q$ which refer to the probabilities of being in the same state $s_{t}$ as in the previous period, i. e.

$$
P\left[s_{t}=1 \mid s_{t-1}=1\right]=p, \quad P\left[s_{t}=0 \mid s_{t-1}=0\right]=q .
$$


Within each regime the relationship between the risk factors and the EUA returns is linear (see equation (1)) and the state variable $s_{t}$, thus, governs the shift between these two linear relationships. The transition probabilities characterize the switching in regimes and therefore the evolvement of the system over time. In order to draw inference on $s_{t}$, we calculate the smoothed probabilities $\operatorname{Pr}\left[s_{t}=j \mid I_{T}\right], j=0,1$ based on the algorithm provided by Kim (1994). The smoothed probabilities are conditional on the information set $I_{T}$ that comprises the entire information contained in the data set.

\section{Empirical Results}

In the following we first provide the estimation results of a linear specification of the relation between the EUA returns and their fundamentals and then present and discuss the empirical results of our nonlinear model.

\subsection{Linear Model}

Following former research on the relation between the EUA price and its fundamentals, we begin our empirical analysis by estimating a linear model, i.e. without regime switches. This allows us to compare our empirical findings to the existing empirical literature and to highlight special features. To this end, we regress the EUA price changes on selected energy variables, a stock index, a commodity index, a default spread, a term spread and a temperature variable reflecting extreme weather conditions in Europe. The model takes the following form

$$
\begin{aligned}
\text { EUA }_{t} & =\beta_{0}+\beta_{1} \mathrm{Oil}_{t}+\beta_{2} \mathrm{Coal}_{t}+\beta_{3} \mathrm{Gas}_{t} \\
& +\beta_{4} \mathrm{DJES} \mathrm{D}_{t}+\beta_{5} \mathrm{CRBI}_{t}+\beta_{6} \text { Default Spread }_{t} \\
& +\beta_{7} \text { Term Spread }_{t}+\beta_{8} \text { Temperature }_{t}+e_{t},
\end{aligned}
$$

where $e_{t}$ refers to the error term at period $t$. As noted previously, apart from the Temperature variable, that is treated as absolute value, we consider the continuously compounded returns of the variables defined in Section 4.1.

The estimation results of the linear model are reported in Table3. As the EUA return series exhibits mild autocorrelation we report Newey-West standard errors, see Newey and West (1987). Concerning the energy variables, our results are primarily in line with the existing literature, as summarized in Section 3 for a brief review. In particular, the estimated impacts of crude oil and natural gas are positive and significant. In contrast to 
Table 3: Estimation results of the linear model.

\begin{tabular}{|c|c|c|}
\hline Variable & Parameter & Std. error ${ }^{a}$ \\
\hline Constant & -0.00599 & $(0.0797)$ \\
\hline Oil & $0.1280^{* *}$ & $(0.0481)$ \\
\hline Coal & 0.0661 & $(0.0524)$ \\
\hline Gas & $0.3501^{* * *}$ & $(0.0665)$ \\
\hline DJES50 & $0.2404^{* * *}$ & $(0.0460)$ \\
\hline CRBI & $0.2883^{*}$ & $(0.1326)$ \\
\hline Default Spread & 0.0515 & $(0.0369)$ \\
\hline Term Spread & -0.00204 & $(0.0027)$ \\
\hline Temperature & 0.0438 & $(0.0295)$ \\
\hline $\mathrm{LM}_{\mathrm{ARCH}} \mathrm{TEST}^{b}$ & 115.533 & $(0.0000)$ \\
\hline
\end{tabular}

The table presents the estimation results of the linear model given in equation $3{ }^{* * *}$ indicates significance at $1 \%,{ }^{* *}$ at $5 \%,{ }^{*}$ at $10 \%$.

$a$ The reported standard errors are Newey-West standard errors.

${ }^{b}$ Test statistic of the Lagrange Multiplier test with $H_{0}$ no ARCH effects up to order five. The number in parentheses provides the corresponding $p$-value.

earlier studies, we find no significant impact of steam coal on EUA returns.

Our estimation results also suggest that the EUA returns are not affected by all considered macroeconomic and financial risk factors. Only the stock index and the commodity index have a highly significant and positive influence. The coefficients of the remaining variables as well as the constant are not statistically different from zero at any conventional levels.

The positive impacts of the stock index and the commodity index are consistent with our expectations: Market participants associate a positive development of stock index values or commodity prices with rising economic activity, which leads to increasing EUA prices. The positive impact of the stock index is also in line with the findings of Chevallier (2009). ${ }^{3}$ Using a different dataset, Hintermann (2010) instead finds no significant impact. The insignificance of the default spread is also observed in Chevallier (2009).

Although previous studies differ in that they consider different sample periods and different sets of fundamentals, all findings presented above support the evidence of a changing nature in the relation between EUA prices and its fundamentals. Note that the Lagrange multiplier test, reported in Table 3, rejects the null of no ARCH effects in the innovations of regression (3) up to the fifth order. This supports once more the necessity to account for volatility clustering when modeling daily EUA returns, see also our results in the empirical data analysis of Section 4.2 . 
Table 4: Results of the MRS - GARCH model.

\begin{tabular}{|c|c|c|c|c|}
\hline \multirow[b]{2}{*}{ Variable } & \multirow{2}{*}{$\begin{array}{l}\text { Regime } 1 \\
\text { Parameter }\end{array}$} & \multirow{2}{*}{$\begin{array}{l}\left(s_{t}=0\right) \\
\text { Std. error }\end{array}$} & \multirow{2}{*}{$\begin{array}{l}\text { Regime } 2 \\
\text { Parameter }\end{array}$} & \multirow{2}{*}{$\begin{array}{l}\left(s_{t}=1\right) \\
\text { Std. error }\end{array}$} \\
\hline & & & & \\
\hline Constant & -0.1085 & $(0.1084)$ & $0.1405^{*}$ & $(0.0767)$ \\
\hline Oil & $0.0980^{* *}$ & $(0.0484)$ & $0.1830^{* * *}$ & $(0.0458)$ \\
\hline Coal & $-0.1422^{* *}$ & $(0.071)$ & $-0.10467^{*}$ & $(0.079)$ \\
\hline Gas & $0.2623^{* * *}$ & $(0.0723)$ & $0.3970^{* * *}$ & $(0.0543)$ \\
\hline DJES50 & $0.2302^{* * *}$ & $(0.20608)$ & $0.1947^{* * *}$ & $(0.0602)$ \\
\hline CRBI & $0.3460^{*}$ & $(0.1890)$ & 0.2234 & $(0.1506)$ \\
\hline Default Spread & 0.0757 & $(0.0539)$ & 0.0156 & $(0.0551)$ \\
\hline Term Spread & -0.00008 & $(0.0073)$ & -0.00486 & $(0.0048)$ \\
\hline Temperature & 0.0662 & $(0.0419)$ & -0.0038 & $(0.0332)$ \\
\hline$\omega$ & $0.8527^{* * *}$ & $(0.3203)$ & - & - \\
\hline$\alpha$ & $0.1070^{* * *}$ & $(0.0384)$ & - & - \\
\hline$\beta$ & $0.7859^{* * *}$ & $(0.0680)$ & - & - \\
\hline uncond. std. dev. of EUA return shocks & \multicolumn{2}{|c|}{$\sigma^{(1)}=7.950$} & \multicolumn{2}{|l|}{$\sigma^{(2)}=1.415$} \\
\hline transition probabilities & \multicolumn{2}{|c|}{$\mathrm{P}\left[s_{t}=0 \mid s_{t-1}=0\right]=0.9485$} & \multicolumn{2}{|c|}{$\mathrm{P}\left[s_{t}=1 \mid s_{t-1}=1\right]=0.9704$} \\
\hline
\end{tabular}

The table shows the estimation results of the Markov regime-switching-GARCH model. ${ }^{* * *}$ indicates significance at $1 \%,{ }^{*}$ at $5 \%,{ }^{*}$ at $10 \%$. The lower panel of the table presents the transition probabilities as well as the unconditional standard deviations of the shocks to the EUA returns in both regimes.

\subsection{Nonlinear Model}

In the following we present our empirical analysis based on the Markov regime-switching (MRS) model discussed in Section 5, i.e. the effects of the risk factors on EUA returns as well as the volatility are allowed to depend on two regimes, we account for GARCH effects and allow for the possibility of structural changes in the volatility. However, we focus on a reduced form of the model. In particular, preliminary estimation results (not shown) indicate that the GARCH parameters $\alpha$ and $\beta$ in the second regime are insignificant $4^{4}$ Therefore, we model the standard deviation of shocks to the EUA returns in the second regime simply by a constant, $\sigma^{(2)}$. The estimation results of our model specification are presented in Table 4. The smoothed probabilities of being in Regime 1 are depicted in Figure 3 .

Our first regime is characterized by no clear price trend but very high unconditional standard deviation of the shocks to the EUA returns, $\sigma^{(1)}$. This state can also be interpreted as a market phase of disorientation. In contrast, the second regime describes a state where mean EUA price changes are positive and significantly different from zero (at the 10 percent level) and where the unconditional standard deviation of the EUA return shocks, $\sigma^{(2)}$, is very low. This state characterizes phases of adjustments to higher price levels that are accompanied by low volatility. Surprisingly, the impact of the considered

\footnotetext{
${ }^{3}$ Note that dividend yields (that have an negative impact on EUA prices according to Chevallier (2009)) are reciprocal to the values of the corresponding stock index.

${ }^{4}$ The results of the preliminary analysis are available upon request.
} 
fundamentals is very similar in both regimes, although the impact of some of the significant factors in Regime 1 seems to be slightly weaker in the second regime. The most important drivers of the EUA price in the first regime are the commodity index, the gas price and the equity index. The oil price has a very weak, even though significant, impact. In the second regime, the oil price and the equity index have about the same impact on the EUA price. The strongest impact in the second regime is observed for the gas price, if all other factors are kept constant.

The influence of gas and oil prices is significant and positive. This is in line with the results of the linear model and with previous research. In contrast, the parameters of coal show negative signs, which is in accordance to the economic intuition described in Section 4.1. In particular, the fuel-switch behavior of the power supply companies implies that in a situation of increasing coal prices the company will ceteris paribus switch to less expensive and in the case of oil and gas less emission-intensive fuels. The equity index shows a significant positive impact on EUA prices in both regimes. This is in line with earlier research and with the results of the linear model. This strong impact reflects the importance of the equity index as a predictor for the general economic development and, thus, for the aggregated demand for allowances. The commodity index is only significant in the first regime - the high volatility regime. Like in the linear model, the interest rate spreads have no significant influence on the EUA price formation.

Furthermore, the results indicate that the volatility is highly persistent in the first regime. The transition probabilities from the first to the second regime and vice versa are very small. In other words, the relation between the EUA price and the considered fundamentals is likely to stay the same.

During the second half of the year 2007 and the first half of the year 2008, the carbon price series shows an upward trend interrupted by a short consolidation phase in January 2008. Except for this consolidation phase, the smoothed probabilities illustrated in the bottom panel of Figure 3 indicate the system to be with high probability in the second regime that is characterized by a low and constant volatility. This is also in line with the behavior of the carbon return series during this year. The smoothed probabilities suggest that the occurrence of the first regime coincides approximately with the economic recession of 2008 and 2009. In this period, economic activity slowed down resulting in lower demand for commodities and in lower overall emissions. As a consequence, commodity and allowance prices decreased dramatically. The return series $r_{t}$ and the conditional volatility $h_{t}$ in Figure 3 show that the uncertainty in the market increased in the second half of 2008 and the first half of 2009. In the time period from early 2009 to August 2010, the carbon price is at a level around EUR 15. During this phase of 
lateral movement, the smoothed probabilities still indicate that the first regime prevails. Also, the conditional volatility is still on higher levels in comparison to the phase of the upward trend in late 2007 and early 2008. This finding suggests, that the strong economic slowdown during the aftermath of the financial crisis sustainably harmed the confidence in a restrictive cap in the framework of the EU ETS. In this kind of situation, the market participants are uncertain about the supply and demand ratio. They fear the market condition of an oversupply of allowances, where the overall cap for the second and third trading period is not binding any more resulting in a sharp price drop. This uncertainty may increase in times, when the expectations about the general economic development deteriorates or information is released that indicates less stringency for the EU ETS.

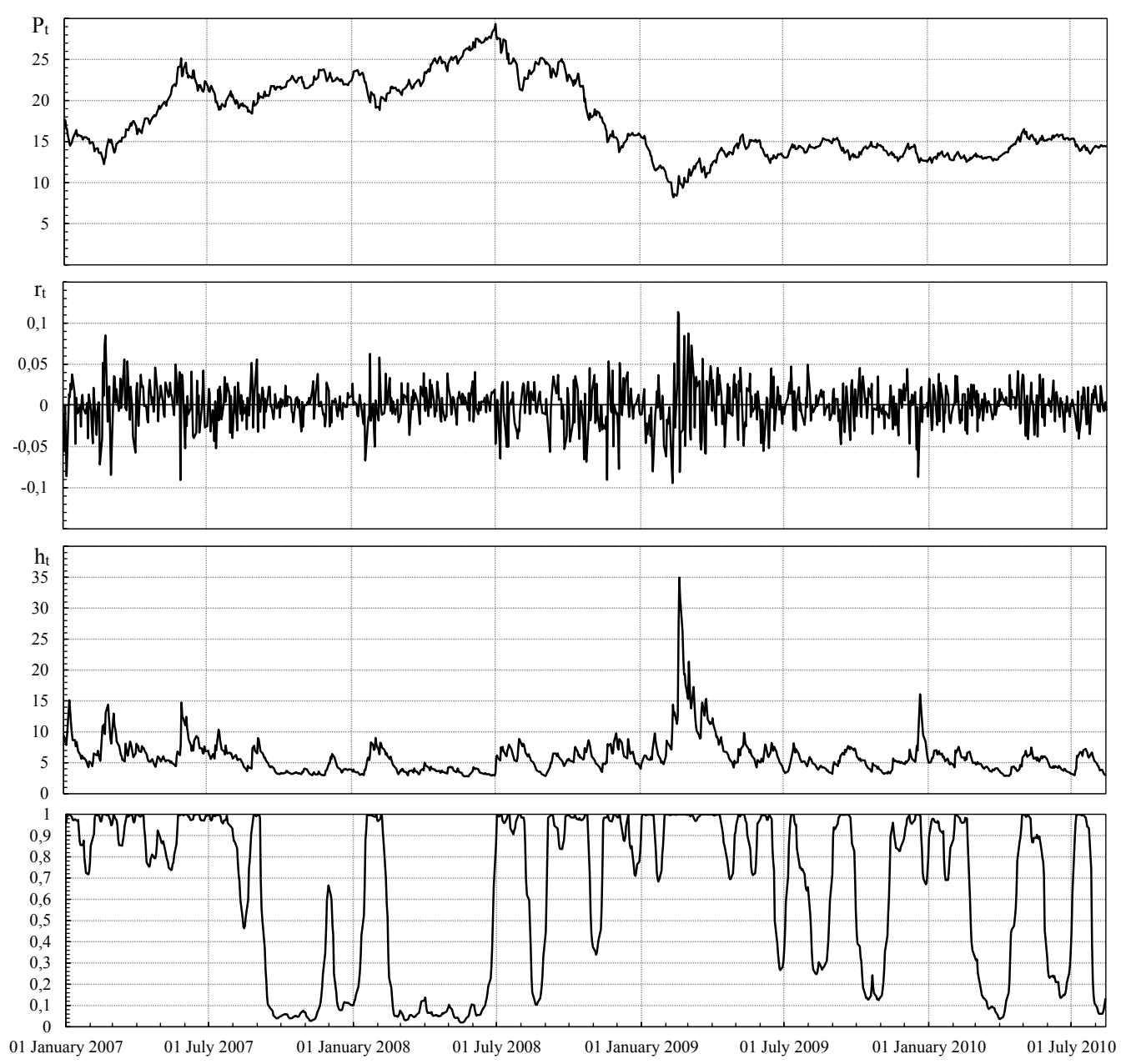

Figure 3: Inference about $s_{t}$ : Carbon futures prices, returns, conditional variance of the first regime and smoothed probabilities for being in the first regime. 


\section{Conclusions}

This paper is concerned with the nonlinear relation between the EUA price and its fundamentals. We argue that changes in the data generating process of the EUA price are a consequence of the design of the EU ETS. In particular, since the EU ETS runs on the basis of a cap-and-trade system, the supply of allowances is fixed over a certain period of time, while the demand is subject to various shocks. When these shocks reduce current emissions and, thus, the current demand for allowances, uncertainty about the overall stringency of the scheme increases and market participants adjust their expectations. The associated trading translates into a higher volatility and a potentially varying relation between the EUA price and its fundamentals. Our empirical results support such a nonlinearity in the dynamics of the EUA price. We estimate a Markov regime-switching GARCH model, accounting for changing states in the mean and variance of the EUA returns. Although our nonlinear model is only able to show slight differences in the impact of the fundamentals across states, it is able to identify a low and a high volatility regime. The high volatility regime largely coincides with the recent economic recession in 2008 and 2009, when the overall actual emissions were on a decline. This supports our idea, that declining emissions increase the uncertainty about the overall stringency among market participants leading to higher volatility. 


\section{References}

Alberola, E., J. Chevallier, and B. Chèze (2008): "Price Drivers and Structural Breaks in European Carbon Prices 2005 - 2007," Energy Policy, 36, 787-797.

- (2009a): "The EU Emissions Trading Scheme: The Effects of Industrial Production and CO2 Emissions on European Carbon Prices," International Economics, 116, 95-128.

(2009b): "Emissions Compliances and Carbon Prices under the EU ETS: A Country Specific Analysis of Industrial Sectors," Journal of Policy Modeling, 31, 446462 .

Anger, N., And U. Oberndorfer (2008): "Firm Performance and Employment in the EU Emissions Trading Scheme: An Empirical Assessment for Germany," Energy Policy, 36(1), 12-22.

Bredin, D., And C. Muckley (2011): "An Emerging Equilibrium in the EU Emissions Trading Scheme," Energy Economics, 33(2), 353-362.

Chevallier, J. (2009): "Carbon Futures and Macroeconomic Risk Factors: A View From the EU ETS," Energy Economics, 31, 614-625.

(2011a): "Evaluating the Carbon-Macroeconomy Relationship: Evidence from Threshold Vector Error-Correction and Markov-switching VAR Models," Economic Modelling, 28(6), 2634-2656.

(2011b): "A Model of Carbon Price Interactions with Macroeconomic and Energy Dynamics," Energy Economics, 33(6), 1295-1312.

Conrad, C., D. Rittler, and W. Rotfuss (2011): "Modeling and Explaining the Dynamics of European Union Allowance Prices at High-Frequency," Energy Economics, (forthcoming).

Demailly, D., And P. Quirion (2008): "European Emission Trading Scheme and Competitiveness: A Case Study on the Iron and Steel Industry," Energy Economics, 30(4), 2009-2027.

Diebold, F. X., And A. Inoue (2001): "Long Memory and Regime Switching," Journal of Econometrics, 105, 131-159. 
Fama, E. F., And K. R. French (1989): "Business Conditions and Expected Returns on Stocks and Bonds," Journal of Financial Economics, 25(1), 23-49.

Granger, C., And N. Hyung (2004): "Occasional Structural Breaks and Long Memory with an Application to the S\&P500 Absolute Returns," Journal of Empirical Finance, 11, 399-421.

Gray, S. F. (1996): "Modeling the Conditional Distribution of Interest Rates as a Regime-switching Process," Journal of Financial Economics, 42(1), 27-62.

Hamilton, J. D. (1989): "A New Approach to the Economic Analysis of Nonstationary Time Series and the Business Cycle," Econometrica, 57(2), 357-384.

Hintermann, B. (2010): "Allowance Price Drivers in the First Phase of the EU ETS," Journal of Environmental Economics and Management, 59, 43-56.

Keppler, J. H., and M. Mansanet-Bataller (2010): "Causalities between CO2, Electricity, and Other Energy Variables During Phase I and Phase II of the EU ETS," Energy Policy, 38(7), 3329-3341.

KIM, C.-J. (1994): "Dynamic linear models with Markov-switching," Journal of Econometrics, 60(1-2), 1-22.

KlaAssen, F. (2002): "Improving GARCH Volatility Forecasts with Regime-switching GARCH," Empirical Economics, 27(2), 363-394.

Klepper, G., and S. Peterson (2004): "The EU Emissions Trading Scheme, Allowance Prices, Trade Flows, Competitiveness Effects," European Environment, 14(4), $201-218$.

Mansanet-Bataller, M., A. Pardo, and E. Valor (2007): "CO2 Prices, Energy and Weather," Energy Journal, 28, 67-86.

Mikosch, T., And C. StăRică (2004): "Non-stationarities in Financial Time Series, the Long Range Dependence and the IGARCH Effects," Review of Economics and Statistics, 86, 378-390.

Newey, W. K., and K. D. West (1987): "A Simple, Positive Semi-definite, Heteroskedasticity and Autocorrelation Consistent Covariance Matrix," Econometrica, 55(3), 703-708. 
Oberndorfer, U., and K. Rennings (2007): "Costs and Competitiveness Effects of the European Union Emissions Trading Scheme," European Environment, 17(1), 1-17.

Paolella, M., and L. Taschini (2008): "An Econometric Analysis of Emission Allowances Prices," Journal of Banking and Finance, 32, 2022-2032.

Peri, M., And L. Baldi ((2011):): "Nonlinear Price Dynamics between CO2 Futures and Brent," Applied Economics Letters, 18(13), 1207-1211.

Sadorsky, P. (2002): "Time-varying Risk Premiums in Petroleum Futures Prices,," Energy Economics, 24, 539-556.

World Bank (2012): State and Trends of the Carbon Market 2012. Carbon Finance at the World Bank. 